\title{
Awareness of BA Translation Students of the Arabic Grammatical Aspects and their Translations into English: A Comparative Study
}

\author{
Mohammad Atawi Sariareh* \\ Translation Department, Yarmouk University, Jordan \\ Haytham Hammad Althawbih \\ Translation Department, German-Jordanian University, Jordan
}

Received on: 31-05-2020

Accepted on: 16-09-2020

\begin{abstract}
This paper aims at measuring the extent of some translation students' competence of grammatical aspect compounds (strings) and their adequacy in rendering them in English. It also tries to establish which strings students tend to mistranslate. The researchers designed a multiple-choice test, using Google form, in which a given Arabic text is provided with four alternatives: one correct answer and three distractors. The test was distributed to students from translation departments at Yarmouk University and the German Jordanian University enrolled in the second semester, 2020 via the E-learning systems. Responses of students (202 out of 300 from YU and 63 out of 86 from GJU) were collected in tables. The researchers used One-way ANOVA and Scheffe Test to analyze the data. The paper has concluded that there are no significant differences among students with regard to gender, study plan, level of study, and taking Arabic courses traditionally taught. However, students joining Yarmouk University and the German-Jordan University from international and private schools are better than those coming from public schools. The majority of students do not have problems with the simple present and simple future and their perfective and progressive aspects, nor do they with past perfect. However, they confuse the perfective and progressive aspects of the simple present and the simple past.
\end{abstract}

Keywords: Grammatical aspects, Arabic grammar, English grammar, Translation Yarmouk University, German-Jordanian University.

\section{Introduction}

Translation is known as a complicated process by which translators tend to attenuate language boundaries in an attempt to reproduce some text of a given source language (SL) in a given Target Language (TL). This goal can only be achieved if the translator recreates the intended meaning as accurately as possible in the TL (Catford 1965, 20; Wills 1982, 20; Newmark 1988, 94). One of the many problems that BA translation students in Jordan may encounter is handling tense+aspect (s) verb structure. This universal complicated phenomenon (Juhfah 2006) may pose a problem to translators because of the many related grammatical features in English and Arabic. Languages exhibit some differences with regard to tense+aspect (perfective and progressive) and their usages, thus, posing problems to translators (Salkie 1989; Baker 1992; Ghazala 1995; Ayad 2012).

\footnotetext{
๑ 2021 JJMLL Publishers/Yarmouk University. All Rights Reserved,

* Doi: https://doi.org/10.47012/jjmll.13.1.10.

* Corresponding Author: saraireh@yu.edu.jo.
} 
English comprises 12 tense+aspects structures (Celce 1999). Early Arab grammarians asserted that Arabic only has three tenses: past, present, and future (Sibawayhi 1988) assuming that there is no tense+aspect structures. Many Western linguists, such as Wright (1898) assume that Modern Classical Arabic and modern dialects employ tense+aspects verb structures.

However, a look into the descriptions of Arabic grammar courses at school and university levels in Arabic Language departments, or Arabic for special purposes, such as Arabic grammar for translation or media purposes shows that these courses are mostly designed on the assumption that Arabic tenses are only three: past, present, and future (not aspects: perfective and progressive). The fact is that tense+aspect verb structures are in actual use in Arabic, and, revealed in the subsequent sections, they are similar to those in English with regard to usage and meaning.

\section{Problem of the Study}

The problem that this study intends to tackle is the assumption that although there are similarities between Arabic and English with regard to tense+aspect verb structures, still these features may pose difficulties to translation students. The main cause for this problem is that Arabic traditional grammar courses at school and university levels assume that there are only three tense structures, namely: past, present, and future, but there are no accompanying aspects (progressive and perfective).

\section{Research Questions:}

The research intends to answer these questions:

a. To what extent are students aware of these tense+aspect verb structures?

b. How adequately can students translate these structures (Arabic-English)?

c. To what extent would the deletion of these structures affect the meaning in translation?

\section{Significance of the Study}

The significance of this study lies in the following: (1) asserting that the Arabic progressive and perfective aspects are also evident even in Classical Arabic and not novel; (2) pointing out the range of awareness of translation students of compounded tenses and aspect verb structures in Arabic; (3) and ability of students to translate sentences with such verb structures into English. (4) It is expected that it provides insights to translation study planners at Jordanian universities to include courses that make students aware of tense awareness.

\section{Research Method}

To conduct this study, the researchers followed this procedure:

\subsection{Data Collection}

\subsubsection{Instrument of Data Collection}

The researchers designed a test of 10 multiple choice items by using Google Form (Appendix 1). Each item measures a certain targeted aspect of Arabic and its translation into English together with three close translations as distractors. The link of the test was distributed through the E-learning systems at Yarmouk University and the German-Jordanian University to the targeted students. The results were collected in tables. 
Awareness of BA Translation Students of the Arabic Grammatical Aspects and their Translations into English: A Comparative Study

The data were analyzed by using One-way ANOVA ${ }^{1}$ and Scheffe Test ${ }^{2}$ and scored in tables.

\subsubsection{Sample of the Study}

The sample of the study consisted of a number of BA students (see tables) in the second semester 2019/2020 in the translation departments at both universities who responded to the test. All students are Jordanians whose mother tongue is Arabic. All of them studied English at school according to the program designed by the Ministry of Education. Some students studied English in International Programs (IG or IB) at private schools. They also took courses in English at university level. All students have studied the same Arabic courses at school and similar courses at university level as university requirements.

\subsection{Variables of the Study}

a. Translation students at YU and GJU.

b. Students' level of study.

c. Gender.

d. Type of school for participants.

e. Experience of participants with regard to Arabic and English grammar courses at both universities.

Both Yarmouk University and the German-Jordanian University are state institutions. The translation study plans are close in both programs and accredited by the Ministry of Higher Education and Scientific Research. Students take Arabic courses as university requirements. There are also Arabic courses as faculty requirements. The translation study plan at YU has two required Arabic grammar courses (Arabic Grammar and Grammar 4) and one elective (Grammar 5). There are also comparative (English-Arabic) courses, namely Advanced Comparative Grammar, Comparative Linguistics, Syntax for Translation Purposes, Grammar and Reading. Students also take two English grammar courses. At GJU, students take Arabic courses at university and faculty requirements. The translation study plan has two Arabic grammar courses. It also offers English courses: Advanced English Grammar and English Syntax and Morphology. The two study plans offer supplementary courses in Arabic rhetoric, morphology, translation theory, practical translation, phonetics and phonology, and listening comprehension. It should be noted that the language of instruction in both programs is mainly English.

\subsection{Data Analysis}

The researchers used One-way ANOVA and Scheffe Test to analyze the data. The results were tabulated and discussed. The findings were interpreted for conclusions.

\section{Related Studies}

The related studies can be classified into two categories:

\subsection{Studies that relate to tense+aspect verb structures in Arabic:}

There are studies that have tackled compound tenses and aspects in Modern Standard Arabic and contemporary Arabic dialects. However, our search in academic databases did not yield any studies that tackled tenses and aspects in Classical Arabic, unlike this study which tries to establish that some of these 
tense+aspect verb structures do exist (Wright 1898; Eisele 1992; Ingham 1994; Brustad 2000; Karin 2005; Joseph 2010; Al-Otaibi 2017).

5.2 Studies that have somehow tackled the issue of compound tenses and aspects in Arabic

Some of them focused on English-into-Arabic translation problems with regard to English tense and aspects, which is not the scope of this study. (Ayad 2000; Gadalla 2006; Younes, 2014; Obeidat 2014; Akan 2019).

\subsection{Studies on the Translation of Arabic tense+aspect Verb Structures into English}

There is only one study that dealt with the translation of Arabic tense+aspect verb structures by Gadalla (2017). The author tackled the strategies of translating Arabic tense+aspect verb structures into English with some examples for training.

The present study is expected to contribute to this field, for it tries to prove that tense+aspect verb structures do exist even in Classical Arabic. It focuses on the translation students' ability to handle them when they translate Arabic texts including them into English.

\section{Theoretical Framework: Tense+Aspects Verb Structures}

6.1 In English:

There are three tenses in English: past, present, and future (Jespersen, 1968), as follows (Celce, 1999):

\begin{tabular}{|c|c|c|c|c|}
\hline & SIMPLE & PERFECT & PROGRESSIVE & $\begin{array}{l}\text { PERFECT } \\
\text { PROGRESSIVE }\end{array}$ \\
\hline Present & $\begin{array}{l}\varnothing \\
\text { Write/writes } \\
\text { Walk/walks }\end{array}$ & $\begin{array}{l}\text { Have + -en } \\
\text { Has/have } \\
\text { written } \\
\text { Has/have } \\
\text { walked }\end{array}$ & $\begin{array}{l}\text { be }+ \text {-ing } \\
\text { am/is/are writing } \\
\text { am/is/are walking }\end{array}$ & $\begin{array}{l}\text { have }+ \text {-en be }+ \text {-ing } \\
\text { has/have been writing } \\
\text { has/have been walking }\end{array}$ \\
\hline Past & $\begin{array}{l}\text { Wrote } \\
\text { Walked } \\
\text { Will write } \\
\text { Will walk }\end{array}$ & $\begin{array}{l}\text { Had written } \\
\text { Had walked } \\
\text { Will have } \\
\text { written } \\
\text { Will have } \\
\text { walked }\end{array}$ & $\begin{array}{l}\text { was/were writing } \\
\text { was/were walking } \\
\text { will be writing } \\
\text { will be walking }\end{array}$ & $\begin{array}{l}\text { had been writing } \\
\text { had been walking } \\
\text { will have been writing } \\
\text { will have been walking }\end{array}$ \\
\hline
\end{tabular}

\subsection{In Arabic}

Early Arab grammarians, such as Sibawyhi $(1988,12)$ advocated three tenses: past, present, and future. Many other grammarians followed him, namely: Az-Zajjaji (1986, 108); Ibn as-Sarraj (1988, 36); Ibn al-Warraq (1999, 308); Ibn Ya'eesh (2001, 426) Az-Zamakhshari (1993, 25); and Ibn Jinni (2005, 23); as well as recent Arab grammarians, namely: Abbas Hasan (2001, 47); Al-Ghalaayni (2004, 33); and Al-Hamlawi $(2005,17)$.

Several modern studies advocate that there are more than the three tense categories: past, present, and future. These studies show that there are also compound verb structures, such as past perfect and past continuous, etc. These studies rely on the Modern Classical Arabic and its daily uses Fassi (1993); Karin (2005); Joseph (2010); and Al-Otaibi (2014). Some other studies rely on Modern spoken dialects in Arab countries, such as Jelinek (1983); Eisele (1992); Ingham (1994); Brustad (2000); Al-Hilal (2011); and AlOtaibi (2017). 
Awareness of BA Translation Students of the Arabic Grammatical Aspects and their Translations into English: A Comparative Study

The problem with these studies is that the early grammarians advocated (past, present, future), thus, asserting that these verb tense+aspect structures (strings), whether in Modern Classical Arabic or Arabic dialects, are novel. We show, in this paper, that tense+aspect verb structures have existed even in Classical Arabic, and not only in Modern forms of Arabic.

\section{1. ان علي قد غادر عندما جاء هيثم إلى البيت Ali had left when Haytham came home.}

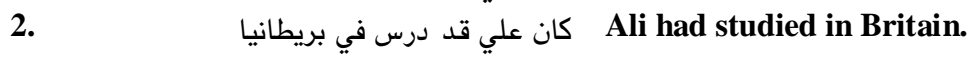

In (1), there is a sequence of two events, both in the past. In Arabic, the structure ( كان + قد فعل ماض ظرف ) is used (Wright (1898); Brustad (2000); Karin (2005); and Al-Otaibi (2017). This structure indicates that an event took place in the past before another, or a distant event in the past like example (2) (as-Samirra'I 2000, 311). Wright (1898) called it "pluperfect." This structure is equivalent to the past perfect in English.

This structure is commonly used in Classical Arabic as in these examples:

وقد كان شهد الجمل فعطبت يده (1410 H, 550) -

- He had witnessed Al-Jamal [battle] and his hand was injured.

قد كان شهد على دفني (المخزومي، 1986،1496) -

- $\underline{\text { He had attended my barrial. }}$
3. كان علي يأكل البارحة.
Ali was eating yesterday.

The structure (كان + فعل مضارع) to indicate a progressive action going on in the past as in (3). Jelinek (1981); Patrick (1998); Brustad (2000); Joseph (2010); and Al-Otaibi (2017). As-Samirra'i (1966, 33) explained that "the structure (yafcal) preceded by (kaan) may come to indicate that it (act) is progressive in the past.” In (3), the adverb (البارحة) which is not needed to indicate a progressive aspect (past+progressive), which also has the same indication in English.

This structure is commonly used in Classical Arabic as in this example:

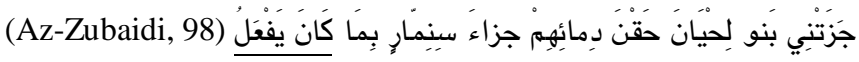

\section{4. ق Ali had been playing for four hours when we arrived.}

We notice that the structure (كان + قد + فعل مضارع + ظرف + فعل ماض) is used to indicate an event that was going on when another past event interrupted it. Most recent studies have overlooked this structure, to the best of our knowledge. In English it indicates a past perfect progressive action.

This structure is commonly used in Classical Arabic as in this example:

$$
\text { يحبك كما قد كان يفعل - Al-Asma'I 1993, 96) }
$$

- He loves you as he used to

$$
\text { 5. علي يدرس }
$$

\section{Ali is studying. / Ali studies.}

In (5), it cannot be established whether (يدرس) indicates simple present (habitual action) or progressive (temporary action). The verb itself in Arabic does not carry any morphemes that indicate a simple form of a progressive form. Therefore, there is a need for an adverb to indicate a progressive 
action, such as (الآن) or any similar adverbs. The context could give a clue whether the verb connotes a progressive simple (static) action.

6. يكون على ما يزال يدرس عندما نصل

\section{Ali will still be studying when we arrive}

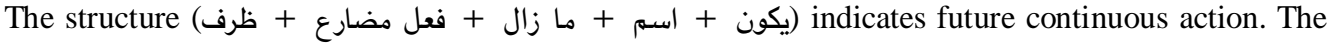
adverb (( ما زال is optional here, but the adverb clause is required in Classical Arabic and Modern Classical Arabic. We find examples like (كان يمشي ليلا: He used to go during the night) (Ad-Dmeri, 1424 H., 78).

However, in dialect sense the structure (يكون + اسم + مضارع فعل) is possible (Benmamoun 2000); and Al-Otaibi 2017) as in (يكون الطالب يدرس الآن: The student is studying now)

The word (يكون) is used for emphasis only, indicating that the student is probably not doing anything else.

7. A تد كتب الطالب المقالة

7. B يكون الطالب كتب المقالة

The student has written the article

In (7. B), (يكون) with a past verb indicates the progress of an action from a point in the past up to the moment of speaking, or recent time (Al-Otaibi 2014). The adverb (قد) may also be used with a past verb (8. A) which corresponds to the present perfect in English.

This is evident in Classical Arabic as in

فرجوت الله أَن يكون قد رَفعهاً عنك وصرفها إلي (Ibn al-Marzuban 1991, 111) -

- تمنى أخيرا أن يكون أطاعني (Al-Dhabbi 1424H., 102)

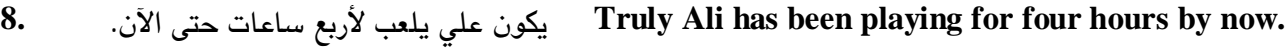

The structure (يكون + فعل مضارع + ظرف) indicates that an event started sometime in recent past and is till going on up to the moment of speaking (Sekhri 2008). This structure corresponds to the present perfect progressive in English. However, the word (يكون) or colloquially (يكون) indicates emphasis. This structure occurs in Modern Classical or colloquial Arabic, but not in Classical Arabic.

\section{Ali will be playing when come home.}

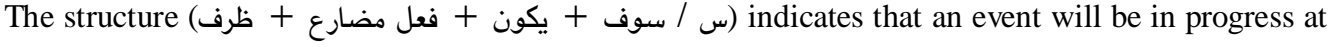
a certain moment in the future (Brustad 2000; Al-Otaibi 2014). This structure corresponds to the future perfect progressive in English. Colloquially, the future prefixes (رح/ / إح) can also be used instead of (سوف / for the same purpose.

This structure is evident in Classical Arabic as in

سيكون بعدي أمراء يعطون الحكمة على منابرهم وقلوبهم أنتن من الجيف (حديث شريف) " -

- (Al-Jahith 1423H., 118)

- There will succeed me rulers who would give wisdom on their pulpits while their heats are stinker than [dead] corpuses. 
Awareness of BA Translation Students of the Arabic Grammatical Aspects and their Translations into English: A Comparative Study

Ali will have written the article when (by the time)
we come home

The structure (س / سوف + يكون + فعل ماض + ظرف) is used to indicate the completion of an event in the future by a certain time or another event (Brustad 2000; Karin 2005). This structure corresponds to the future perfect structure in English. In colloquial Arabic, the prefixes $ح$ / (رح) can also be used. For example, رح يكون زيد كتب الرسالة مبكرا

This structure is commonly used in Classical Arabic as in

- سيكون بعد ستين سنة خلف أضاعوا الصلاة (حديث شريف) (Ibn Al-Atheer 1979, 66)

There will come sixty years later people who abandoned the [prescribed] prayers

\section{Data Analysis, Discussion, and Findings}

In this section, the researchers discuss question items one at a time. All question items are listed in Appendix 1. We should point out that the number of female students in both departments is significantly higher than that of male students, which explains some of the figures in the tables. One-way ANOVA is used in the analysis.

\subsection{Overall Performance of Participants}

Table 1: Frequencies of Responses of Participants at GJU and YU.

\begin{tabular}{|c|c|c|c|c|c|c|c|c|}
\hline & $\mathrm{N}$ & Mean & \multirow{2}{*}{$\frac{\text { Standard }}{\text { deviation }}$} & \multirow{2}{*}{$\begin{array}{l}\text { Descriptives } \\
\text { Std. Error }\end{array}$} & \multicolumn{2}{|c|}{$95 \%$ Confidence } & \multirow[t]{2}{*}{ Min } & \multirow[t]{2}{*}{ Max } \\
\hline & & & & & Lower & Upper & & \\
\hline GJU & 63 & 7.9048 & 4.07080 & .51287 & 6.8795 & 8.9300 & 0.00 & 10.00 \\
\hline YU & 202 & 7.6733 & 4.23585 & .29803 & 7.0856 & 8.2609 & 0.00 & 10.00 \\
\hline Total & 265 & 7.7283 & 4.19074 & .25743 & 7.2214 & 8.2352 & 0.00 & 10.00 \\
\hline \multicolumn{9}{|c|}{ ANOVA } \\
\hline & & \multicolumn{2}{|c|}{ Sum of Squares } & Mer & Mean Square & $\mathrm{F}$ & \multicolumn{2}{|c|}{ Sig. } \\
\hline \multicolumn{2}{|l|}{ Between Groups } & \multicolumn{2}{|c|}{2.574} & 1 & 2.574 & .146 & \multicolumn{2}{|c|}{0.703} \\
\hline \multicolumn{2}{|l|}{ Within Groups } & \multicolumn{2}{|c|}{4633.864} & 263 & \multirow[t]{2}{*}{17.619} & & & \\
\hline Total & & \multicolumn{2}{|c|}{4636.438} & 264 & & & & \\
\hline
\end{tabular}

Table 1 shows that the means of correct responses for YU students, who could translate tense+aspect verb structures, is (7.67); and (7.9) for GJU students. These values indicate that students at both institutions are aware of these structures and capable of translating them. The differences between the two groups are statistically insignificant at $(0.05 \geq \alpha)$ with SIG $(0.703)$ which indicates close levels of students at both universities. This could be related to similarity of study plans in both departments, and, even though Arabic courses have the conventional past, present, and future tense categories, students are capable of dealing with such structures on the basis of daily usage, and not formal instruction. 
Saraireh, Althawbih

7.2 Performance of Participants with regard to gender difference

Table 2: statistics with regard to the gender variable.

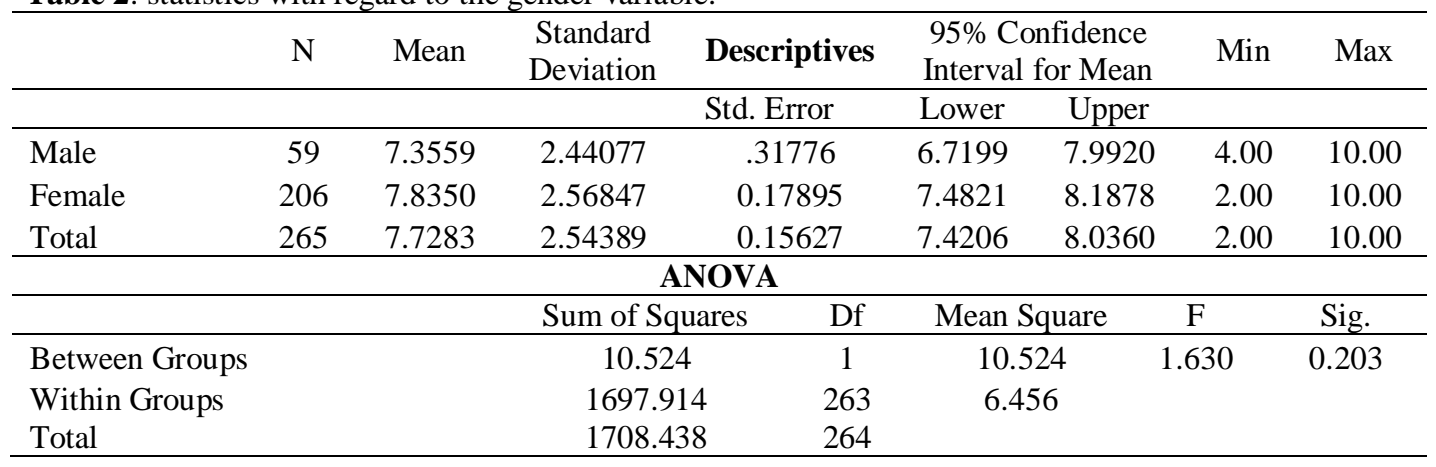

Table 2 indicates that the means of correct responses for males and females are close with (7.35) for males and (7.83) for females. The results also show that there is not a statistically significant difference between the two groups at $(0.05 \geq \alpha)$ with SIG of $(0.203)$. So, the gender variable is not significant.

\subsection{The School Variable}

Table 3: Frequencies of Correct Responses with regard to schools.

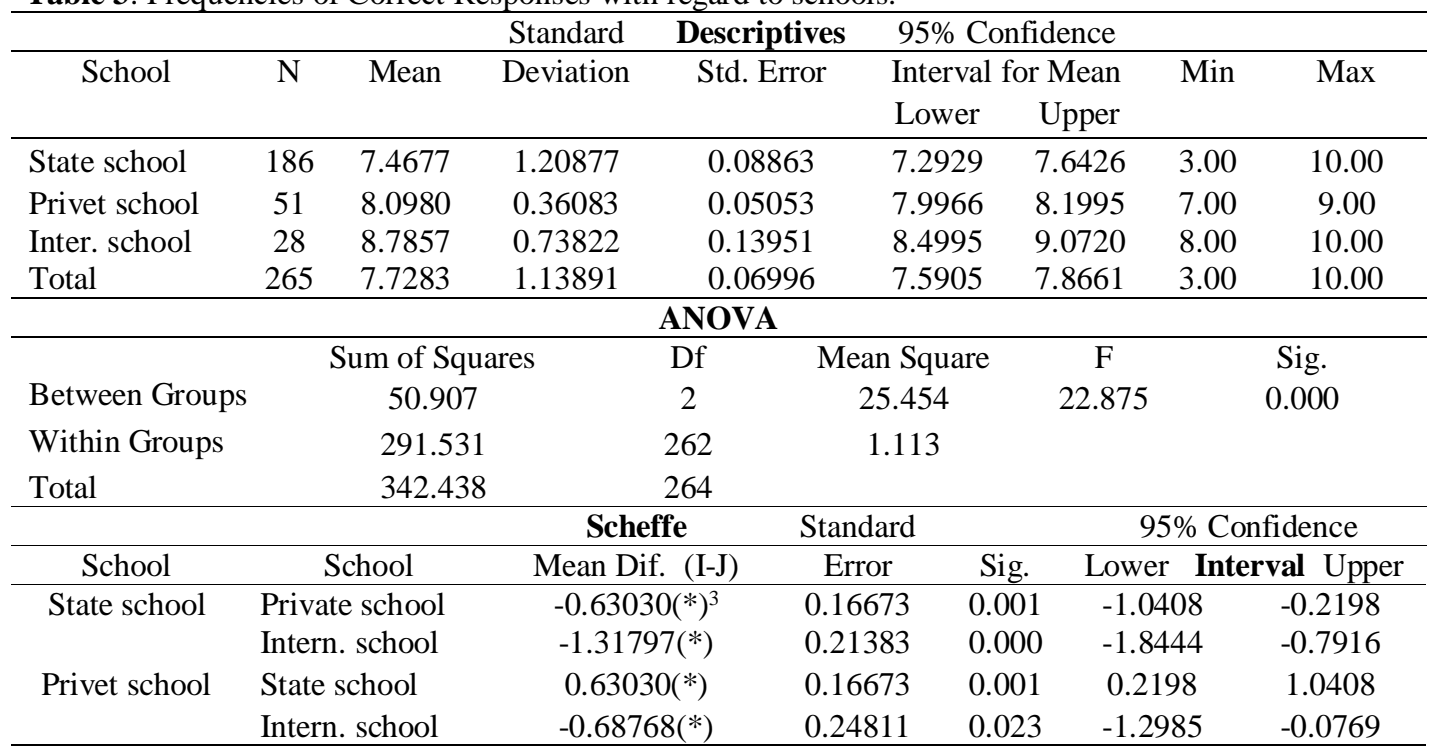

Table 3 tells that students who attended international schools could translate these verb structures adequately. The mean of correct responses for both groups is (8.78), followed by students of private schools with (8.09), then public schools with (7.46). The language of instruction at international schools is English which explains their adequate handling of such verb structures. Private schools offer intensive English courses which also enable their students to comprehend such verb structures and translate them adequately. However, English programs in public schools are not as sufficient. However, those students make use of their knowledge of the English verb structures and use it to deal with those in Arabic, which resulted in the scores in Table 3. Scheffe Test indicates that there are statistically differences among the three school groups at $(0.05 \geq \alpha)$ with regard to SIG values. 
Awareness of BA Translation Students of the Arabic Grammatical Aspects and their Translations into English: A Comparative Study

\subsection{Effect of Arabic Courses on Participants}

The figures in Table 4 show that the means of correct response of the students who have taken Arabic courses (7.75) and those who have not (7.74) are identical. There are not statistically significant differences at $(0.05 \geq \alpha)$, with SIG $(0.953)$. This could be related to the fact that instructors of Arabic do not even hint to that Arabic does have verb structures other than just past, present, past. This indicates the ineffectiveness of Arabic courses at this level with regard to the verb structures in question. Students are aware of such verb structures by comparisons with that of English and their daily practice in modern forms of Arabic.

Table 4: Correlations between Correct Responses and Arabic Courses.

\begin{tabular}{|c|c|c|c|c|c|c|c|c|}
\hline \multicolumn{9}{|c|}{ Descriptives } \\
\hline & \multirow[t]{2}{*}{$\mathrm{N}$} & \multirow[t]{2}{*}{ Mean } & \multirow[t]{2}{*}{$\begin{array}{c}\text { Std. } \\
\text { Deviation }\end{array}$} & \multirow[t]{2}{*}{ Std. Error } & \multicolumn{2}{|c|}{$\begin{array}{l}\text { 95\% Confidence } \\
\text { Interval for Mean }\end{array}$} & \multirow[t]{2}{*}{ Min } & \multirow[t]{2}{*}{ Max } \\
\hline & & & & & Lower & Upper & & \\
\hline $\begin{array}{l}\text { The students have } \\
\text { not studied syntax }\end{array}$ & 43 & 7.7442 & 1.39886 & 0.21332 & 7.3137 & 8.1747 & 5.00 & 10.00 \\
\hline $\begin{array}{l}\text { The students have } \\
\text { studied syntax }\end{array}$ & 222 & 7.7568 & 1.27074 & 0.08529 & 7.5887 & 7.9248 & 5.00 & 10.00 \\
\hline Total & 265 & 7.7547 & 1.28961 & 0.07922 & 7.5987 & 7.9107 & 5.00 & 10.00 \\
\hline \multicolumn{9}{|c|}{ ANOVA } \\
\hline & \multicolumn{2}{|c|}{ Sum of Squares } & Df & Mean Square & \multicolumn{2}{|c|}{$\mathrm{F}$} & \multicolumn{2}{|c|}{ Sig. } \\
\hline Between Groups & \multicolumn{2}{|c|}{0.006} & 1 & \multirow{2}{*}{$\begin{array}{l}0.006 \\
1.669\end{array}$} & \multicolumn{2}{|c|}{0.003} & \multicolumn{2}{|c|}{0.953} \\
\hline Within Groups & \multicolumn{2}{|c|}{439.051} & 263 & & & & & \\
\hline Total & \multicolumn{2}{|c|}{439.057} & 264 & & & & & \\
\hline
\end{tabular}

\subsection{Effect of University Level}

Table 5: Correlations of Correct Responses and University Level.

\begin{tabular}{|c|c|c|c|c|c|c|c|c|}
\hline \multicolumn{9}{|c|}{ Descriptives } \\
\hline \multirow[t]{2}{*}{$\begin{array}{c}\text { University } \\
\text { Level }\end{array}$} & \multirow[t]{2}{*}{$\mathrm{N}$} & \multirow[t]{2}{*}{ Mean } & \multirow[t]{2}{*}{$\begin{array}{c}\text { Std. } \\
\text { Deviation }\end{array}$} & \multirow[t]{2}{*}{ Std. Error } & \multicolumn{2}{|c|}{$\begin{array}{l}\text { 95\% Confidence } \\
\text { Interval for Mean }\end{array}$} & \multirow[t]{2}{*}{ Min } & \multirow[t]{2}{*}{ Max } \\
\hline & & & & & Lower & Upper & & \\
\hline First year & 44 & 7.5909 & 1.70250 & 0.25666 & 7.0733 & 8.1085 & 5.00 & 10.00 \\
\hline Second year & 68 & 7.6765 & 1.40830 & 0.17078 & 7.3356 & 8.0174 & 5.00 & 10.00 \\
\hline Third year & 66 & 7.7273 & 1.71460 & 0.21105 & 7.3058 & 8.1488 & 1.00 & 10.00 \\
\hline Fourth year & 72 & 7.8056 & 1.66690 & 0.19645 & 7.4139 & 8.1973 & 4.00 & 10.00 \\
\hline Fifth year & 15 & 7.8667 & 1.88478 & 0.48665 & 6.8229 & 8.9104 & 5.00 & 10.00 \\
\hline Total & 265 & 7.7208 & 1.62525 & 0.09984 & 7.5242 & 7.9173 & 1.00 & 10.00 \\
\hline \multicolumn{9}{|c|}{ ANOVA } \\
\hline & & \multicolumn{2}{|c|}{ Sum of Squares } & Df & \multicolumn{2}{|c|}{ Mean Square } & $\mathrm{F}$ & Sig. \\
\hline \multicolumn{2}{|l|}{ Between Groups } & \multicolumn{2}{|r|}{1.715} & 4 & \multicolumn{2}{|c|}{0.429} & 0.160 & 0.958 \\
\hline Within Groups & & \multicolumn{2}{|c|}{695.621} & 260 & \multicolumn{2}{|c|}{2.675} & & \\
\hline Total & & \multicolumn{2}{|c|}{697.336} & 264 & & & & \\
\hline
\end{tabular}

Table 5 illustrates that the means of correct responses do not seem to be influenced by university level of participants. The values do not show statistically significant differences (minimally (7.59) and maximally (7.86)) related to the different levels of students at $(0.05 \geq \alpha)$ with SIG of (0.958). This is against the assumption that the higher the level the better the performance of students. This indicates that the courses that students take do not address the verb structures in question though there are abundant in practical translation courses. 


\section{Analysis of Participants' Responses to Each of the Questions:}

In the following sections, we provide detailed analyses of the responses of the participants to each of the test questions.

\subsection{Handling the Past Perfect}

Table 6: Results of Responses to Question 1 (Past perfect)

\begin{tabular}{|c|c|c|c|c|c|c|c|c|}
\hline \multicolumn{9}{|c|}{ Descriptives } \\
\hline \multirow[b]{2}{*}{ Question options } & \multirow[t]{2}{*}{$\mathrm{N}$} & \multirow[t]{2}{*}{ Mean } & \multirow[t]{2}{*}{$\begin{array}{c}\text { Std. } \\
\text { Deviation }\end{array}$} & \multirow[t]{2}{*}{$\begin{array}{c}\text { Std. } \\
\text { Error }\end{array}$} & \multicolumn{2}{|c|}{$\begin{array}{l}95 \% \text { Confidence } \\
\text { Interval for Mean }\end{array}$} & \multirow[t]{2}{*}{ Min } & \multirow[t]{2}{*}{ Max } \\
\hline & & & & & \multicolumn{2}{|c|}{ Lower Upper } & & \\
\hline Past perfect & 265 & 0.7509 & 0.43328 & 0.02662 & 0.6985 & 0.8034 & 0.00 & 1.00 \\
\hline Past progressive & 265 & 0.0792 & 0.27063 & 0.01662 & 0.0465 & 0.1120 & 0.00 & 1.00 \\
\hline Simple past & 265 & 0.0981 & 0.29803 & 0.01831 & 0.0621 & 0.1342 & 0.00 & 1.00 \\
\hline Future perfect & 265 & 0.0755 & 0.26465 & 0.01626 & 0.0435 & 0.1075 & 0.00 & 1.00 \\
\hline Total & 1060 & 0.2509 & 0.43376 & 0.01332 & 0.2248 & 0.2771 & 0.00 & 1.00 \\
\hline \multicolumn{9}{|c|}{ Multiple Comparisons/ Scheffe } \\
\hline \multirow{2}{*}{\multicolumn{3}{|c|}{ Question options }} & $\begin{array}{c}\text { Mean } \\
\text { Difference (I-J) }\end{array}$ & $\begin{array}{l}\text { Std. } \\
\text { Error }\end{array}$ & Sig. & \multicolumn{3}{|c|}{ 95\% Confidence Interval } \\
\hline & & & & & & Lower & & \\
\hline \multirow{3}{*}{ Past perfect } & \multicolumn{2}{|c|}{ Past progressive } & $0.67170(*)$ & 0.02815 & 0.000 & 0.5929 & \multicolumn{2}{|c|}{0.7505} \\
\hline & \multicolumn{2}{|c|}{ Simple past } & $0.65283(*)$ & 0.02815 & 0.000 & 0.5740 & \multicolumn{2}{|c|}{0.7316} \\
\hline & \multicolumn{2}{|c|}{ Future perfect } & $0.67547(*)$ & 0.02815 & 0.000 & 0.5967 & \multicolumn{2}{|c|}{0.7543} \\
\hline \multirow[t]{2}{*}{ Past progressive } & \multicolumn{2}{|c|}{ Simple past } & -0.01887 & 0.02815 & 0.930 & -0.0977 & \multicolumn{2}{|c|}{0.0599} \\
\hline & \multicolumn{2}{|c|}{ Future perfect } & 0.00377 & 0.02815 & 0.999 & -0.0750 & \multicolumn{2}{|c|}{0.0826} \\
\hline Simple past & \multicolumn{2}{|c|}{ Future perfect } & 0.02264 & 0.02815 & 0.886 & -0.0562 & \multicolumn{2}{|c|}{0.1014} \\
\hline
\end{tabular}

Table 6 illustrates that $(\% 75.09)^{4}$ of the students are capable of handling the past perfect aspect. This indicates that they know that the auxiliary (كان) with (تد) signify this aspect. Other students (\%9.81) choose simple past, which is indicatively somewhat close the past perfect. Students might assume that since the two verbs occurred in the past, they can be displayed with simple past- Also, (\%7.55) choose the future perfect, which is too far because this requires a future morpheme (سوف / wich is not there. Others (\%7.92) selected the past progressive, an unjustified choice because it requires (كان) as in the following section. Scheffe Test shows that there are statistically significant differences among the distractors to the benefit of the one with past perfect at $(0.05 \geq \alpha)$ with $(0.00)$ for SIG. 
Awareness of BA Translation Students of the Arabic Grammatical Aspects and their Translations into English: A Comparative Study

\subsection{Handling the Past Progressive (Question 2)}

Table 7: Results of Responses to Question 2 (Past Progressive).

\begin{tabular}{|c|c|c|c|c|c|c|c|c|c|}
\hline \multicolumn{10}{|c|}{ Descriptives } \\
\hline \multirow[b]{2}{*}{ Question options } & \multirow[t]{2}{*}{$\mathrm{N}$} & \multirow[t]{2}{*}{ Mean } & \multirow[t]{2}{*}{$\begin{array}{c}\text { Std. } \\
\text { Deviation }\end{array}$} & \multirow{2}{*}{\multicolumn{2}{|c|}{$\begin{array}{l}\text { Std. } \\
\text { Error }\end{array}$}} & \multicolumn{2}{|c|}{$\begin{array}{l}\text { 95\% Confidence } \\
\text { Interval for Mean }\end{array}$} & \multirow[t]{2}{*}{ Min } & \multirow[t]{2}{*}{ Max } \\
\hline & & & & & & Lower & Upper & & \\
\hline Past progressive & 1.00 & 265 & 0.8189 & \multicolumn{2}{|c|}{0.38586} & 0.02370 & 0.7722 & 0.8655 & 0.00 \\
\hline Past perfect & 2.00 & 265 & 0.0491 & \multicolumn{2}{|c|}{0.21639} & 0.01329 & 0.0229 & 0.0752 & 0.00 \\
\hline Present perfect & 3.00 & 265 & 0.0264 & \multicolumn{2}{|c|}{0.16067} & 0.00987 & 0.0070 & 0.0458 & 0.00 \\
\hline $\begin{array}{l}\text { Present perfect } \\
\text { progressive }\end{array}$ & 4.00 & 265 & 0.1057 & \multicolumn{2}{|c|}{0.30798} & 0.01892 & 0.0684 & 0.1429 & 0.00 \\
\hline Total & Total & 1060 & 0.2500 & \multicolumn{2}{|c|}{0.43322} & 0.01331 & 0.2239 & 0.2761 & 0.00 \\
\hline \multicolumn{10}{|c|}{ Multiple Comparisons/ Scheffe } \\
\hline \multirow[t]{2}{*}{ Question options } & & & \multirow{2}{*}{\multicolumn{2}{|c|}{$\begin{array}{c}\text { Mean } \\
\text { Difference (I-J) }\end{array}$}} & \multirow{2}{*}{\multicolumn{2}{|c|}{ Std. Error }} & \multirow[t]{2}{*}{ Sig. } & \multicolumn{2}{|c|}{$95 \%$ Confidence Interval } \\
\hline & & & & & & & & Lower & Upper \\
\hline \multirow{3}{*}{ Past progressive } & \multicolumn{2}{|c|}{ Past perfect } & \multicolumn{2}{|c|}{$0.76981(*)$} & \multicolumn{2}{|c|}{0.02443} & 0.000 & 0.7014 & 0.8382 \\
\hline & \multicolumn{2}{|c|}{ Present perfect } & \multicolumn{2}{|c|}{$0.79245(*)$} & \multicolumn{2}{|c|}{0.02443} & 0.000 & 0.7240 & 0.8609 \\
\hline & \multicolumn{2}{|c|}{$\begin{array}{l}\text { Present perfect } \\
\text { progressive }\end{array}$} & \multicolumn{2}{|c|}{$0.71321(*)$} & \multicolumn{2}{|c|}{0.02443} & 0.000 & 0.6448 & 0.7816 \\
\hline \multirow[b]{2}{*}{ Past perfect } & Prese & perfect & 0.022 & & & 2443 & 0.835 & -0.0458 & 0.0911 \\
\hline & $\begin{array}{r}\text { Prese } \\
\text { pro }\end{array}$ & $\begin{array}{l}\text { perfect } \\
\text { essive }\end{array}$ & -0.056 & & & 2443 & 0.147 & -0.1250 & 0.0118 \\
\hline Present perfect & $\begin{array}{r}\text { Prese } \\
\text { pro }\end{array}$ & $\begin{array}{l}\text { perfect } \\
\text { essive }\end{array}$ & -0.0792 & & & 2443 & 0.015 & -0.1477 & -0.0108 \\
\hline
\end{tabular}

Table 7 indicates that translation students do not seem to have a problem in rendering the Past Progressive with (\%81.89) correct responses. Scheffe Test shows statistically significant differences to the benefit of the Past Progressive at $(0.05 \geq \alpha)$ with $(0.00)$ SIG. However, $(\% 10.57)$ of the students selected the Present Perfect Progressive. This could be related the present perfect in reality indicates an event that started at some point in the past with completion at the moment of speaking.

\subsection{Handling the Past Perfect Progressive}

As figures in Table 8 show, it is evident that translation students have a problem in dealing with the Past Perfect Progressive in Arabic. Only (\%41.51) of the students are capable of handling this aspect. This could be related to confusing the basic difference between the Past perfect and the present perfect regardless of being progressive or not because both somehow indicate a past event. This actually indicates poor competence of students in this regard. Scheffe Test points out statistically significant differences to the benefit of these two aspects at $(0.05 \geq \alpha)$ with $(0.00)$ SIG in contrast with other two, indicating that most students tended toward these two aspects. This means that students should be made aware of the difference between the two aspects. 
Table 8: Results of Responses to Question 3 (Past Perfect Progressive).

\begin{tabular}{|c|c|c|c|c|c|c|c|c|c|c|c|}
\hline \multicolumn{12}{|c|}{ Descriptives } \\
\hline \multirow{2}{*}{\multicolumn{2}{|c|}{ Question options }} & \multirow[t]{2}{*}{$\mathrm{N}$} & \multirow[t]{2}{*}{ Mean } & \multirow[t]{2}{*}{$\begin{array}{c}\text { Std. } \\
\text { Deviation }\end{array}$} & \multirow{2}{*}{\multicolumn{2}{|c|}{$\begin{array}{l}\text { Std. } \\
\text { Error }\end{array}$}} & \multicolumn{3}{|c|}{$\begin{array}{l}95 \% \text { Confidence } \\
\text { Interval for Mean }\end{array}$} & \multirow[t]{2}{*}{ Mini } & \multirow[t]{2}{*}{ Maxi } \\
\hline & & & & & & & Lower & Upp & & & \\
\hline \multicolumn{2}{|c|}{ Past perfect progressive } & 265 & 0.4151 & 0.49367 & \multicolumn{2}{|c|}{0.03033} & 0.3554 & \multicolumn{2}{|c|}{0.4748} & 0.00 & 1.00 \\
\hline \multicolumn{2}{|l|}{ Present progressive } & 265 & 0.0453 & 0.20832 & \multicolumn{2}{|c|}{0.01280} & 0.0201 & \multicolumn{2}{|c|}{0.0705} & 0.00 & 1.00 \\
\hline \multicolumn{2}{|l|}{$\begin{array}{l}\text { Present perfect } \\
\text { progressive }\end{array}$} & 265 & 0.5132 & 0.50077 & \multicolumn{2}{|c|}{0.03076} & 0.4526 & \multicolumn{2}{|c|}{0.5738} & 0.00 & 1.00 \\
\hline Future perfect & & 265 & 0.0264 & 0.16067 & \multicolumn{2}{|c|}{0.00987} & 0.0070 & \multicolumn{2}{|c|}{0.0458} & 0.00 & 1.00 \\
\hline Total & & 1060 & 0.2500 & 0.43322 & \multicolumn{2}{|c|}{0.01331} & 0.2239 & \multicolumn{2}{|c|}{0.2761} & 0.00 & 1.00 \\
\hline \multicolumn{12}{|c|}{ Multiple Comparisons/ Scheffe } \\
\hline \multirow{2}{*}{\multicolumn{2}{|c|}{ Question options }} & & \multirow{2}{*}{\multicolumn{3}{|c|}{ Mean Difference (I-J) }} & \multirow{2}{*}{\multicolumn{2}{|c|}{ Std. Error }} & \multirow[t]{2}{*}{ Sig. } & \multicolumn{3}{|c|}{$95 \%$ Confidence } \\
\hline & & & & & & & & & & & Upper \\
\hline \multirow{3}{*}{$\begin{array}{l}\text { Past perfect } \\
\text { progressive }\end{array}$} & \multicolumn{3}{|c|}{ Present progressive } & \multicolumn{2}{|c|}{$0.36981(*)$} & & 3261 & 0.000 & \multicolumn{2}{|c|}{0.2785} & 0.4611 \\
\hline & \multirow{2}{*}{\multicolumn{3}{|c|}{$\begin{array}{l}\text { Pres. perf. prog. } \\
\text { Future perfect }\end{array}$}} & \multicolumn{2}{|c|}{$-0.09811(*)$} & & 3261 & 0.029 & & 1894 & -0.0068 \\
\hline & & & & 0.388 & $(*)$ & 0.0 & & 0.000 & & 974 & 0.4800 \\
\hline Present proore & $\operatorname{Pr}$ & perf. 1 & og. & -0.46 & $2(*)$ & 0.0 & 261 & 0.000 & & 592 & -0.3766 \\
\hline Present progressive & $\mathrm{Fu}$ & re perf & & 0.018 & & 0.0 & 261 & 0.953 & & 724 & 0.1102 \\
\hline Pres. perf. prog. & $\mathrm{Fu}$ & re perf & & 0.486 & $(*)$ & 0.0 & 261 & 0.000 & & 955 & 0.5781 \\
\hline
\end{tabular}

8.4 Handling the Present perfect

Table 9: Results of Responses to Question 4 (Present Perfect).

\begin{tabular}{|c|c|c|c|c|c|c|c|c|c|c|}
\hline \multicolumn{11}{|c|}{ Descriptives } \\
\hline \multirow[t]{2}{*}{ Question options } & \multirow[t]{2}{*}{$\mathrm{N}$} & \multirow[t]{2}{*}{ Mean } & \multirow[t]{2}{*}{$\begin{array}{l}\text { Std. } \\
\text { Deviation }\end{array}$} & \multirow{2}{*}{\multicolumn{2}{|c|}{$\begin{array}{l}\text { Std. } \\
\text { Error }\end{array}$}} & \multicolumn{3}{|c|}{$\begin{array}{l}\text { 95\% Confidence } \\
\text { Interval for Mean }\end{array}$} & \multirow[t]{2}{*}{ Min } & \multirow[t]{2}{*}{ Max } \\
\hline & & & & & & \multicolumn{3}{|c|}{ Lower Upper } & & \\
\hline Present perfect & 265 & 0.8189 & 0.38586 & \multicolumn{2}{|c|}{0.02370} & \multicolumn{2}{|c|}{0.7722} & 0.8655 & 0.00 & 1.00 \\
\hline $\begin{array}{l}\text { Present perfect } \\
\text { progressive }\end{array}$ & 265 & 0.0491 & 0.21639 & \multicolumn{2}{|c|}{0.01329} & \multicolumn{2}{|c|}{0.0229} & 0.0752 & 0.00 & 1.00 \\
\hline $\begin{array}{l}\text { Past perfect } \\
\text { progressive }\end{array}$ & 265 & 0.0264 & 0.16067 & \multicolumn{2}{|c|}{0.00987} & \multicolumn{2}{|c|}{0.0070} & 0.0458 & 0.00 & 1.00 \\
\hline Future perfect & 265 & 0.1057 & 0.30798 & \multicolumn{2}{|c|}{0.01892} & \multicolumn{2}{|c|}{0.0684} & 0.1429 & 0.00 & 1.00 \\
\hline Total & 1060 & 0.2500 & 0.43322 & \multicolumn{2}{|c|}{0.01331} & 0.223 & & 0.2761 & 0.00 & 1.00 \\
\hline \multicolumn{11}{|c|}{ Multiple Comparisons/ Scheffe } \\
\hline \multirow[t]{2}{*}{ Question options } & & \multirow{2}{*}{\multicolumn{3}{|c|}{ Mean Difference (I-J) }} & \multirow{2}{*}{\multicolumn{2}{|c|}{ Std. Error }} & \multirow[t]{2}{*}{ Sig. } & \multicolumn{3}{|c|}{$\begin{array}{l}\text { 95\% Confidence } \\
\text { Interval }\end{array}$} \\
\hline & & & & & & & & Lov & & Upper \\
\hline \multirow[t]{3}{*}{ Present perfect } & \multicolumn{2}{|c|}{ Pres perf prog } & \multicolumn{2}{|c|}{$0.76981(*)$} & \multicolumn{2}{|c|}{0.02443} & 0.000 & \multicolumn{2}{|c|}{0.7014} & 0.8382 \\
\hline & Past & orog & 0.79245( & & & 2443 & 0.000 & 0.72 & & 0.8609 \\
\hline & Futu & fect & 0.71321( & & & 2443 & 0.000 & 0.6 & & 0.7816 \\
\hline Pres perf prog & Past & orog & 0.02264 & & 0.0 & 2443 & 0.835 & -0.0 & & 0.0911 \\
\hline & Futu & fect & -0.05660 & & & 2443 & 0.147 & -0.1 & & 0.0118 \\
\hline Past perf prog & Futu & fect & -0.07925 & & & 2443 & 0.015 & -0.1 & & -0.0108 \\
\hline
\end{tabular}

As evident in Table 9, (\%81.89) of the translation students do not have a problem with translating the Present Perfect in Arabic. However, (\%10.57) selected future perfect, (\%4.91) present perfect progressive, and (\%2.64) as past perfect progressive. These figures indicate that a low percentage of the students confuse the present perfect with other perfective aspects. It not too strange to discover a low percentage of students who have problems with Arabic and English grammars, let alone handling them in terms of translation. Scheffe Test shows statistically significant differences to the benefit of the Present Perfect at $(0.05 \geq \alpha)$ with $(0.00)$ SIG. 
Awareness of BA Translation Students of the Arabic Grammatical Aspects and their Translations into English: A Comparative Study

8.5 Handling the Present Progressive

Table 10: Results of Responses to Question 5 (Present Progressive).

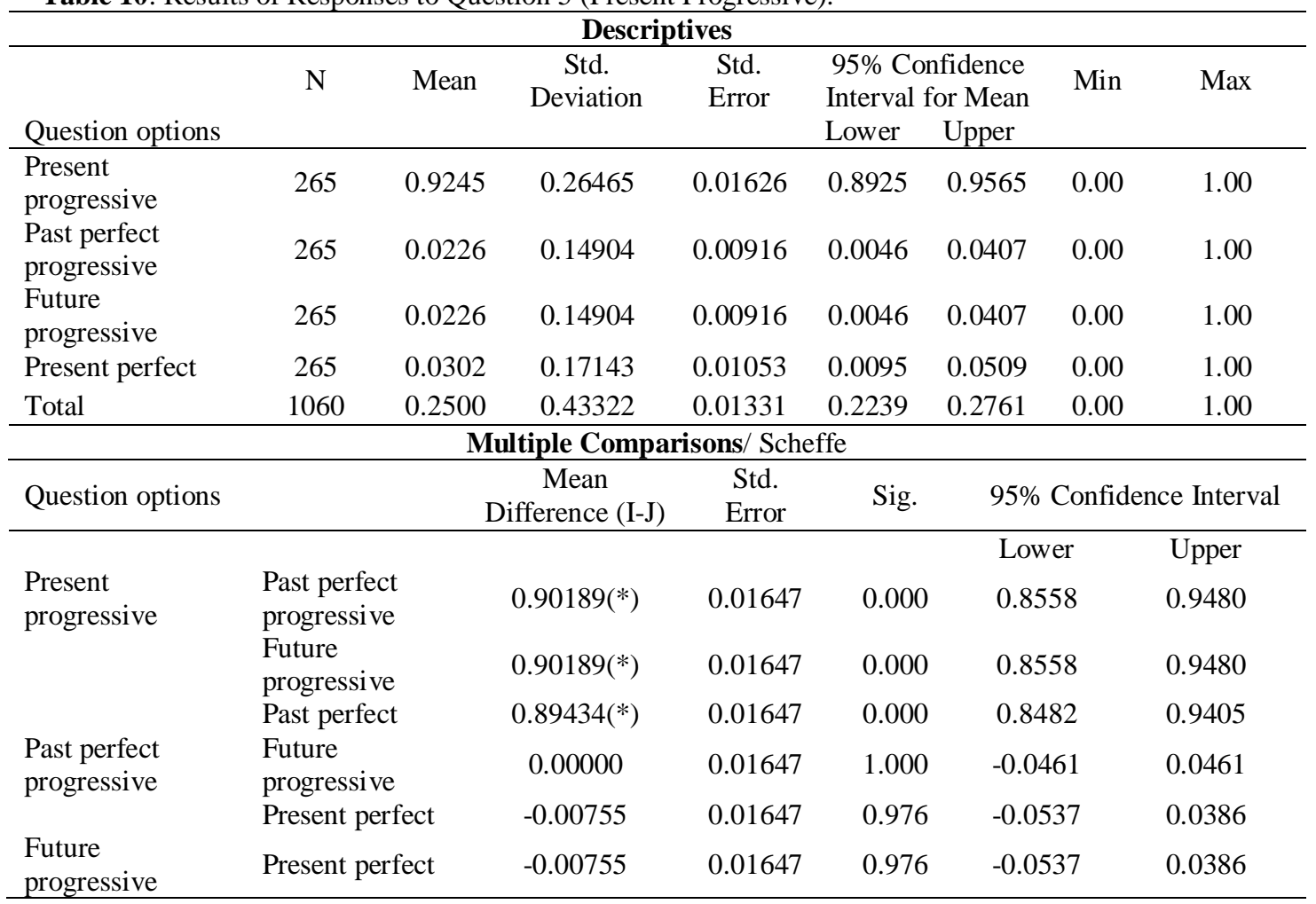

Table 10 shows that (\%92.45) of the students find handling the Present Progressive quite easy. This could be related to the fact that this aspect is transparent enough in English and in Arabic. It is not as sophisticated as the other aspects. Scheffe Test indicates statistically significant differences to the benefit of the Present Progressive at $(0.05 \geq \alpha)$ with $(0.00)$ SIG.

\subsection{Handling the Present Perfect Progressive}

Also, Table 11 shows that $(94.34 \%)$ of the students do not have a problem with handling the Present Perfect Progressive in Arabic and English. It can be noticed that a majority of the students do not have problems with the simple present and related aspects. This might be due to the transparency of this tense and its perfective and progressive aspects. Scheffe Test indicates statistically significant differences to the benefit of the Present Perfect Progressive at $(0.05 \geq \alpha)$ with $(0.00)$ SIG. 
Table 11: Results of Responses to Question 6 (Present Perfect Progressive).

\begin{tabular}{|c|c|c|c|c|c|c|c|c|c|c|}
\hline \multicolumn{11}{|c|}{ Descriptives } \\
\hline \multirow[t]{2}{*}{ Question options } & \multirow[t]{2}{*}{$\mathrm{N}$} & \multirow[t]{2}{*}{ Mean } & \multirow[t]{2}{*}{$\begin{array}{c}\text { Std. } \\
\text { Deviation }\end{array}$} & \multirow{2}{*}{\multicolumn{2}{|c|}{$\begin{array}{l}\text { Std. } \\
\text { Error }\end{array}$}} & \multicolumn{3}{|c|}{$\begin{array}{l}95 \% \text { Confidence } \\
\text { Interval for Mean }\end{array}$} & \multirow[t]{2}{*}{ Min } & \multirow[t]{2}{*}{ Max } \\
\hline & & & & & & \multicolumn{2}{|c|}{ Lower } & Upper & & \\
\hline $\begin{array}{l}\text { Present perfect } \\
\text { progressive }\end{array}$ & 265 & 0.9434 & 0.23152 & \multicolumn{2}{|c|}{0.01422} & \multicolumn{2}{|c|}{0.9154} & 0.9714 & 0.00 & 1.00 \\
\hline Past progressive & 265 & 0.0377 & 0.19092 & \multicolumn{2}{|c|}{0.01173} & \multicolumn{2}{|c|}{0.0146} & 0.0608 & 0.00 & 1.00 \\
\hline Simple past & 265 & 0.0000 & 0.00000 & \multicolumn{2}{|c|}{0.00000} & \multicolumn{2}{|c|}{0.0000} & 0.0000 & 0.00 & .00 \\
\hline Present progressive & 265 & 0.0189 & 0.13632 & \multicolumn{2}{|c|}{0.00837} & \multicolumn{2}{|c|}{0.0024} & 0.0354 & 0.00 & 1.00 \\
\hline Total & 1060 & 0.2500 & 0.43322 & \multicolumn{2}{|c|}{0.01331} & & 39 & 0.2761 & 0.00 & 1.00 \\
\hline \multicolumn{11}{|c|}{ Multiple Comparisons/ Scheffe } \\
\hline \multirow[t]{2}{*}{ Question options } & & & \multirow{2}{*}{\multicolumn{2}{|c|}{$\begin{array}{c}\text { Mean } \\
\text { Difference } \\
(\mathrm{I}-\mathrm{J})\end{array}$}} & \multirow{2}{*}{\multicolumn{2}{|c|}{$\begin{array}{l}\text { Std. } \\
\text { Error }\end{array}$}} & Sig. & \multicolumn{3}{|c|}{$\begin{array}{l}\text { 95\% Confidence } \\
\text { Interval }\end{array}$} \\
\hline & & & & & & & & \multicolumn{2}{|c|}{ Lower } & Upper \\
\hline \multirow{3}{*}{$\begin{array}{l}\text { Present perfect } \\
\text { progressive }\end{array}$} & \multicolumn{2}{|c|}{ Past progressive } & \multicolumn{2}{|c|}{$0.90566(*)$} & \multicolumn{2}{|c|}{0.01432} & 0.000 & \multicolumn{2}{|c|}{0.8656} & 0.9457 \\
\hline & Simpl & & 0.9434 & & 0.01 & 32 & 0.000 & 0.90 & & 0.9835 \\
\hline & Presen & rogressive & 0.9245 & & 0.01 & 32 & 0.000 & $0.8 \varepsilon$ & & 0.9646 \\
\hline Past nroorescive & Simpl & & 0.037 & & 0.01 & 32 & 0.074 & -0.0 & & 0.0778 \\
\hline rast pingessive & Presen & rogressive & 0.018 & & 0.01 & & 0.629 & -0.0 & & 0.0590 \\
\hline Simple past & Presen & cogressive & $-0.01 \xi$ & & 0.01 & & 0.629 & -0.0 & & 0.0212 \\
\hline
\end{tabular}

\subsection{Handling the Future Perfect (with an adverb)}

Table 12: Results of Responses to Question 7 (Future Perfect).

\begin{tabular}{|c|c|c|c|c|c|c|c|c|c|}
\hline \multicolumn{10}{|c|}{ Descriptives } \\
\hline \multirow{2}{*}{ Question options } & \multirow[t]{2}{*}{$\mathrm{N}$} & \multirow[t]{2}{*}{ Mean } & \multirow[t]{2}{*}{ Deviation } & \multirow[t]{2}{*}{ Error } & \multicolumn{3}{|c|}{$95 \%$ Conf Interval/Mean } & \multirow[t]{2}{*}{ Min } & \multirow[t]{2}{*}{$\operatorname{Max}$} \\
\hline & & & & & \multicolumn{2}{|c|}{ Lower } & Upper & & \\
\hline Future perfect & 265 & 0.7547 & 0.43107 & 0.02648 & \multicolumn{2}{|c|}{0.7026} & 0.8069 & 0.00 & 1.00 \\
\hline Present perfect & 265 & 0.0830 & 0.27643 & 0.01698 & \multicolumn{2}{|c|}{0.0496} & 0.1165 & 0.00 & 1.00 \\
\hline Past perfect & 265 & 0.1509 & 0.35867 & 0.02203 & \multicolumn{2}{|c|}{0.1076} & 0.1943 & 0.00 & 1.00 \\
\hline Simple past & 265 & 0.0113 & 0.10600 & 0.00651 & \multicolumn{2}{|c|}{-0.0015} & 0.0241 & 0.00 & 1.00 \\
\hline Total & 1060 & 0.2500 & 0.43322 & 0.01331 & \multicolumn{2}{|c|}{0.2239} & 0.2761 & 0.00 & 1.00 \\
\hline \multicolumn{10}{|c|}{ Multiple Comparisons/ Scheffe } \\
\hline \multirow[t]{2}{*}{ Question options } & & & \multirow{2}{*}{\multicolumn{2}{|c|}{ Mean Dif. (I-J) }} & \multirow[t]{2}{*}{ Std. Error } & Sig. & \multirow{2}{*}{\multicolumn{3}{|c|}{$\begin{array}{l}\text { 95\% Confidence Interval } \\
\text { Lower } \quad \text { Upper }\end{array}$}} \\
\hline & & & & & & & & & \\
\hline \multirow{3}{*}{ Future perfect } & \multicolumn{2}{|c|}{$\begin{array}{l}\text { Present } \\
\text { perfect }\end{array}$} & \multicolumn{2}{|c|}{$0.67170(*)$} & 0.02754 & 0.000 & 0.5946 & \multicolumn{2}{|c|}{0.7488} \\
\hline & \multicolumn{2}{|c|}{ Past perfect } & \multicolumn{2}{|c|}{$0.60377(*)$} & \multirow{2}{*}{$\begin{array}{l}0.02754 \\
0.02754\end{array}$} & 0.000 & 0.5266 & \multicolumn{2}{|c|}{0.6809} \\
\hline & \multicolumn{2}{|c|}{ Simple past } & \multicolumn{2}{|c|}{$0.74340(*)$} & & 0.000 & 0.6663 & & 205 \\
\hline & Past & erfect & -0.067 & & 2754 & 0.108 & -0.1450 & & 092 \\
\hline Present perfect & Simp & past & 0.071 & & 2754 & 0.080 & -0.0054 & & 488 \\
\hline Past perfect & Simp & past & 0.13962 & & 2754 & 0.000 & 0.0625 & & \\
\hline
\end{tabular}

The results manifested in Table 12 point out that more than three-fourths (\%75.47) do not have a problem with handling Future Perfect in Arabic. However, (\%15.09) of the students selected the Past Perfect. This could be related to the confusion of the two aspects because of their poor competence in Arabic and English grammars. Scheffe Test shows statistically significant differences to the benefit of the Future Perfect at $(0.05 \geq \alpha)$ with $(0.00)$ SIG. It also indicates differences to the benefit of Present Perfect with the other aspects. 
Awareness of BA Translation Students of the Arabic Grammatical Aspects and their Translations into English: A Comparative Study

8.8 Handling the Future Perfect (two future events)

Table 13: Results of Responses to Question 8 (Future Perfect).

\begin{tabular}{|c|c|c|c|c|c|c|c|c|c|c|}
\hline \multicolumn{11}{|c|}{ Descriptives } \\
\hline \multirow{2}{*}{\multicolumn{2}{|c|}{ Question options }} & $\mathrm{N}$ & Mean & $\begin{array}{c}\text { Std. } \\
\text { Deviation }\end{array}$ & $\begin{array}{c}\text { Std. } \\
\text { Error }\end{array}$ & \multicolumn{3}{|c|}{$\begin{array}{l}95 \% \text { Confidence } \\
\text { Interval for Mean }\end{array}$} & Min & Max \\
\hline & & & & & & Lower & \multicolumn{2}{|c|}{ Upper } & & \\
\hline \multirow{2}{*}{\multicolumn{2}{|c|}{$\begin{array}{l}\text { Future perfect } \\
\text { Future perfect } \\
\text { progressive }\end{array}$}} & 265 & 0.5698 & 0.49604 & 0.03047 & 0.5098 & \multicolumn{2}{|c|}{0.6298} & 0.00 & 1.00 \\
\hline & & 265 & 0.3811 & 0.48658 & 0.02989 & 0.3223 & \multicolumn{2}{|c|}{0.4400} & 0.00 & 1.00 \\
\hline \multicolumn{2}{|c|}{ Future simple } & 265 & 0.0151 & 0.12216 & 0.00750 & 0.0003 & \multicolumn{2}{|c|}{0.0299} & 0.00 & 1.00 \\
\hline \multicolumn{2}{|c|}{ Present progressive } & 265 & 0.0377 & 0.19092 & 0.01173 & 0.0146 & \multicolumn{2}{|c|}{0.0608} & 0.00 & 1.00 \\
\hline \multicolumn{2}{|c|}{ Total } & 1060 & 0.2509 & 0.43376 & 0.01332 & 0.2248 & \multicolumn{2}{|c|}{0.2771} & 0.00 & 1.00 \\
\hline \multicolumn{11}{|c|}{ Multiple Comparisons/ Scheffe } \\
\hline \multirow{2}{*}{\multicolumn{2}{|c|}{ Question options }} & & \multirow{2}{*}{\multicolumn{2}{|c|}{$\begin{array}{c}\text { Mean } \\
\text { Difference (I-J) }\end{array}$}} & \multirow[t]{2}{*}{ Std. Error } & \multirow{2}{*}{\multicolumn{2}{|c|}{ Sig. }} & \multicolumn{3}{|c|}{$\begin{array}{l}\text { 95\% Confidence } \\
\text { Interval }\end{array}$} \\
\hline & & & & & & & & & & Upper \\
\hline \multirow{3}{*}{ Future perfect } & \multicolumn{3}{|c|}{$\begin{array}{l}\text { Future perfect } \\
\text { progressive }\end{array}$} & $0.18868(*)$ & 0.03175 & \multicolumn{2}{|c|}{0.000} & \multicolumn{2}{|c|}{0.0998} & 0.2776 \\
\hline & \multicolumn{3}{|c|}{ Future simple } & $0.55472(*)$ & 0.03175 & \multicolumn{2}{|c|}{0.000} & \multicolumn{2}{|c|}{0.4658} & 0.6436 \\
\hline & \multicolumn{3}{|c|}{ Present progressive } & $0.53208(*)$ & 0.03175 & \multicolumn{2}{|c|}{0.000} & & 432 & 0.6210 \\
\hline Future perfect & & e simpl & & $0.36604(*)$ & 0.03175 & 0.0 & & & 771 & 0.4549 \\
\hline progressive & & nt prog & sive & $0.34340(*)$ & 0.03175 & 0.0 & & & 545 & 0.4323 \\
\hline Future simple & $\operatorname{Pr}$ & nt prog & sive & -0.02264 & 0.03175 & 0.9 & & -0 . & 115 & 0.0663 \\
\hline
\end{tabular}

Table 13 portraits that only (\%56.98) of the students do not encounter a problem with the Future Perfect aspect in Arabic. Moreover, (\%75.47) of them selected this aspect for question (7). It can be noticed that when there is an adverb of future time, the majority of the students can safely identify the correct alternative of such verb structures. In contrast, a lower percentage of the students (about \%57) could select the correct alternative of verb structures when there are two future events. This could be related to the familiarity of students with the (by time) structure more than with two future events, especially that the verb in the adverb clause is with its simple form. Scheffe Test statistically indicates significant differences to the benefit of the future perfect and the future perfect progressive in contrast with the other ones at $(0.05 \geq \alpha)$ with $(0.00)$ SIG.

8.9 Handling the Future Progressive

Table 14: Results of Responses to Question 9 (Future Progressive).

\begin{tabular}{|c|c|c|c|c|c|c|c|c|c|c|}
\hline \multicolumn{11}{|c|}{ Descriptives } \\
\hline \multirow{2}{*}{\multicolumn{2}{|c|}{ Question options }} & $\mathrm{N}$ & Mean & Std Deviation & $\begin{array}{l}\text { Std } \\
\text { Error }\end{array}$ & \multicolumn{3}{|c|}{$\begin{array}{l}95 \% \text { Confidence } \\
\text { Interval for Mean }\end{array}$} & \multirow[t]{2}{*}{ Min } & \multirow[t]{2}{*}{ Max } \\
\hline & & & & & & \multicolumn{2}{|c|}{ Lower } & Upper & & \\
\hline \multicolumn{2}{|c|}{ Future progressive } & 265 & 0.8491 & 0.35867 & 0.02203 & \multicolumn{2}{|c|}{0.8057} & 0.8924 & 0.00 & 1.00 \\
\hline \multicolumn{2}{|c|}{ Future perfect } & 265 & 0.0264 & 0.16067 & 0.00987 & \multicolumn{2}{|c|}{0.0070} & 0.0458 & 0.00 & 1.00 \\
\hline \multicolumn{2}{|l|}{ Simple future } & 265 & 0.0528 & 0.22412 & 0.01377 & \multicolumn{2}{|c|}{0.0257} & 0.0799 & 0.00 & 1.00 \\
\hline \multicolumn{2}{|c|}{ Simple future /passive } & 265 & 0.0717 & 0.25848 & 0.01588 & 0.0 & & 0.1030 & 0.00 & 1.00 \\
\hline \multicolumn{2}{|c|}{ Total } & 1060 & 0.2500 & 0.43322 & 0.01331 & 0.2 & & 0.2761 & 0.00 & 1.00 \\
\hline \multicolumn{11}{|c|}{ Multiple Comparisons/ Scheffe } \\
\hline \multirow{2}{*}{\multicolumn{4}{|c|}{ Question options }} & \multirow[t]{2}{*}{ Mean Dif. (I- } & \multirow{2}{*}{\multicolumn{2}{|c|}{ Std. Error }} & \multirow[t]{2}{*}{ Sig. } & \multicolumn{3}{|c|}{$95 \%$ Conf. Interval } \\
\hline & & & & & & & & \multicolumn{2}{|c|}{ Lower } & Upper \\
\hline \multirow{3}{*}{$\begin{array}{l}\text { Future } \\
\text { progressive }\end{array}$} & \multicolumn{3}{|c|}{ Future perfect } & $0.82264 *$ & \multicolumn{2}{|c|}{0.02263} & 0.0 & 0.75 & & 0.8860 \\
\hline & \multicolumn{3}{|c|}{ Future simple } & $0.79623 *$ & \multicolumn{2}{|c|}{0.02263} & 0.0 & 0.73 & & 0.8596 \\
\hline & Sim & le futur & /passive & $0.77736^{*}$ & 0.02 & 263 & 0.0 & 0.71 & & 0.8407 \\
\hline & Fut & e simpl & & -0.02642 & 0.02 & 263 & 0.7 & -0.08 & & 0.0370 \\
\hline & Sim & e futur & /passive & -0.04528 & 0.02 & 263 & 0.2 & -0.10 & & 0.0181 \\
\hline Simple future & Sim & le futur & /passive & -0.01887 & 0.02 & 263 & 0.8 & -0.08 & & 0.0445 \\
\hline
\end{tabular}


As Table 14 shows that (\%84.91) of the students do not face a problem in handling the Future Progressive in Arabic. This could be related to the fact that this aspect is not complicated for comprehension and translation. Scheffe Test indicates statistically significant differences to the benefit of this aspect compared to the other aspects with $(0.05 \geq \alpha)$ with $(0.00)$ SIG.

\subsection{Handling the Future Perfect Progressive}

Table 15: Results of Responses to Question 10 (Future perfect Progressive).

\begin{tabular}{|c|c|c|c|c|c|c|c|c|}
\hline \multicolumn{9}{|c|}{ Descriptives } \\
\hline & \multirow[t]{2}{*}{$\mathrm{N}$} & \multirow[t]{2}{*}{ Mean } & \multirow[t]{2}{*}{$\begin{array}{c}\text { Std. } \\
\text { Deviation }\end{array}$} & \multirow[t]{2}{*}{$\begin{array}{l}\text { Std. } \\
\text { Error }\end{array}$} & \multicolumn{2}{|c|}{$\begin{array}{l}\text { 95\% Confidence } \\
\text { Interval for Mean }\end{array}$} & \multirow[t]{2}{*}{ Min } & \multirow[t]{2}{*}{ Max } \\
\hline & & & & & Lower & Upper & & \\
\hline $\begin{array}{l}\text { Future perfect } \\
\text { progressive }\end{array}$ & 265 & 0.8151 & 0.38896 & 0.02389 & 0.7680 & 0.8621 & 0.00 & 1.00 \\
\hline Future perfect & 265 & 0.0377 & 0.19092 & 0.01173 & 0.0146 & 0.0608 & 0.00 & 1.00 \\
\hline Simple future & 265 & 0.0075 & 0.08671 & 0.00533 & -0.0029 & 0.0180 & 0.00 & 1.00 \\
\hline Present progressive & 265 & 0.1396 & 0.34725 & 0.02133 & 0.0976 & 0.1816 & 0.00 & 1.00 \\
\hline Total & 1060 & 0.2500 & 0.43322 & 0.01331 & 0.2239 & 0.2761 & 0.00 & 1.00 \\
\hline \multicolumn{9}{|c|}{ Multiple Comparisons/ Scheffe } \\
\hline \multirow[t]{2}{*}{ Question options } & & \multirow{2}{*}{\multicolumn{2}{|c|}{ Mean Dif. (I-J) }} & Std. Error & Sig. & \multicolumn{3}{|c|}{$95 \%$ Confidence Interval } \\
\hline & & & & & & Lower & & \\
\hline \multirow{3}{*}{$\begin{array}{l}\text { Future perfect } \\
\text { progressive }\end{array}$} & Future perfect & \multicolumn{2}{|c|}{$.77736(*)$} & .02441 & .000 & .7090 & \multicolumn{2}{|c|}{.8457} \\
\hline & Simple future & \multicolumn{2}{|c|}{$.80755(*)$} & .02441 & .000 & .7392 & \multicolumn{2}{|r|}{.8759} \\
\hline & Present prog. & \multicolumn{2}{|c|}{$.67547(*)$} & .02441 & .000 & 6071 & \multicolumn{2}{|r|}{.7438} \\
\hline \multirow{2}{*}{ Future perfect } & Simple future & \multicolumn{2}{|c|}{.03019} & .02441 & .676 & -.0382 & \multicolumn{2}{|r|}{.0985} \\
\hline & Present prog. & \multicolumn{2}{|c|}{$-.10189(*)$} & .02441 & .001 & -.1702 & \multicolumn{2}{|c|}{-.0335} \\
\hline Simple future & Present prog. & \multicolumn{2}{|c|}{$-.13208(*)$} & .02441 & .000 & -.2004 & \multicolumn{2}{|c|}{-.0637} \\
\hline
\end{tabular}

According to Table 15, (\%81.51) of the students are comfortable with the comprehension and, thus, translation of the Future Perfect Progressive aspect in Arabic. It seems that the students, generally speaking, find it fairly easy to handle the Future Tense and related aspects because they are not complicated in the sense that there are several events that have to be arranged. Scheffe Test indicates statistically significant differences to the benefit of the Future Perfect Progressive among the other aspects at $(0.05 \geq \alpha)$ with $(0.00)$ SIG.

\section{Conclusions}

On the basis of the analysis and interpretation of findings, the researchers could come up with the following conclusions:

1. Most of tense+aspect verb structures in Arabic are not novel. They have always been there even in Classical Arabic. This study has brought up several examples to prove this point.

2. Translation students are already aware of these verb structures and can handle most of the adequately in translation.

3. There are no statistically significant differences among students with regard to the gender variable.

4. The study also shows that graduates of International and private schools are more competent in English probably because they are exposed to intensive English courses. Also, some of the subjects are taught in English. 
Awareness of BA Translation Students of the Arabic Grammatical Aspects and their Translations into English: A Comparative Study

5. The study has not come up with statistically significant differences between students who have taken Arabic grammar courses at university level and those who have not. This could be related to the fact that Arabic grammar is taught in the traditional method which assumes that Arabic has three simple tenses: past, present, and future ignoring the fact that Arabic can also demonstrate aspects: perfective and progressive, just like English.

6. The study shows that there are no statistically significant differences related to the university level of study in both universities in handling the verb structures in question. This conclusion refutes the idea that the higher the level the better the performance of the students. This could be related to that instructors do not pay sufficient attention to these verb structures even though they keep recurring in texts in practical translation courses.

7. Some students seem to confuse between the simple past and the past perfect. Students may consider it possible to use simple past here because the events are both in the past ignoring the sequence of occurrence. They also confuse between the present perfect progressive and the past perfect progressive. This could be due the inability to measure the time from the moment of speaking thinking that both aspects are in the past (prior to the moment of speaking). They also confuse present perfect progressive for the present perfect. Here, students cannot tell the difference between focusing on the event itself or the duration of the time of the event. Actually, the difference may be too subtle for the students to detect. By the same token, students also confuse future perfect progressive for future perfect. Again, students here are not aware of the subtle difference between the two.

\section{Recommendations}

1. Reconsider the classification of the Arabic verb structure to include the perfective and progressive aspects alongside the three simple tenses.

2. Design an Arabic grammar text that shows the building up of simple tenses and perfective and progressive aspects to teaching with the use of (كان) and the other aspect-indicating elements: (قد) and (سوف).

3. Reconsider Arabic language courses offered at school level, and Arabic grammar courses at university level, especially in translation departments according the conclusions of this study. 


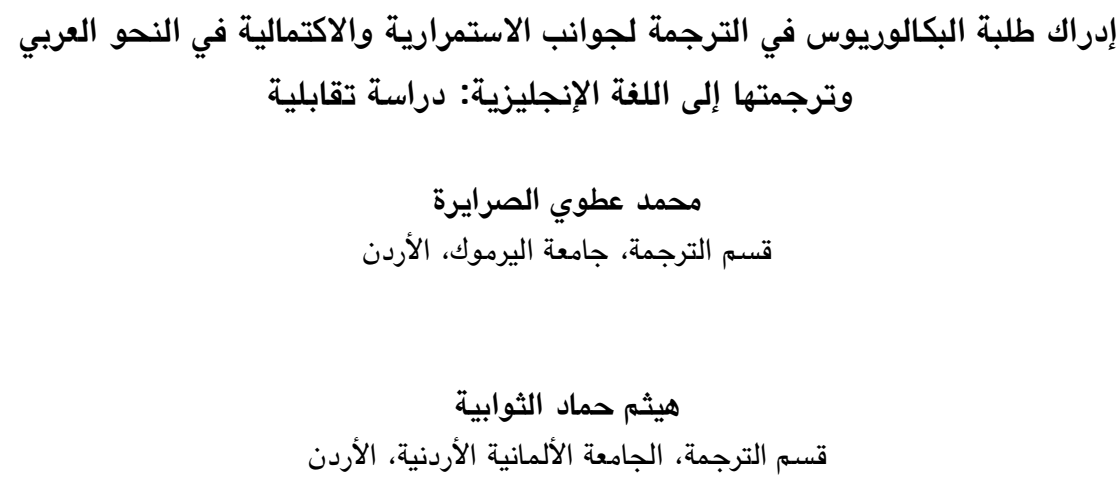


Awareness of BA Translation Students of the Arabic Grammatical Aspects and their Translations into English: A Comparative Study

\section{Endnotes}

${ }^{1}$ A one-way ANOVA is a type of statistical test that compares the variance in the group means within a sample whilst considering only one independent variable or factor. It is a hypothesis-based test, meaning that it aims to evaluate multiple mutually exclusive theories about our data.

${ }^{2}$ The Scheffe Test (also called Scheffe's procedure or Scheffe's method) is a post-hoc test used in Analysis of Variance. It is named for the American statistician Henry Scheffe.... If you want to compare all possible simple and complex pairs of means, run the Scheffe test as it will have a narrower confidence interval.

$3 *$ The mean difference is significant at the. 05 level.

${ }^{4}$ This, and similar figures, is calculated by multiplying the mean by $100(0.7509 * 100=75.09)$.

\section{References}

Al-Asma'i, Abdu 1-Malik. 1993. Al-Asma'iyyat. Ahamd Shakir and Abdu s-Salam Haroun (Verfiers). $7^{\text {th }}$ Edition, Dar l-Ma'arif, Egypt.

Abbas, Hasn. 2001. An-Nahwu l-Wafi. 15 ${ }^{\text {th }}$ Edition. Daru 1-Ma'arif, Egypt.

Adh-Dhabbi, Al-Fadhl. 1983 Amthalu l-Arab. Third Edition. Ihsan Abbas (verifier). Daru r-Ra'd alArabi. Beirut.

Ad-Dumaiyri, Muhammad Ibn Musa. 1424. Hayatu l-Haywan l-Kubra. Second Edition. Daru 1-Kutibi 1'Ilmiyyah. Beirut.

Al-Ghalayni, Mustafa. 2004. Jami' Durusu l-Arabiyyah. 28 ${ }^{\text {th }}$ Edition. Al-Maktabatu 1-Asriyyah. Beirut.

Al-Hamlawi, Ahmad ibnu Muhammad. 2005. Shatha l-'Urf fi fanni s-Sarfi. Nasru 1-Laah Abdu rRahman. Maktabat Rashie. Riyadh.

Al-Hilal. 2011. The syntax of Conditional Sentences in Syrian Arabic: A study based on the dialect of Deir Ezour. PhD diss., University of Essex.

Al-Jahith, Amr ibnu Bahr. 1410. Al-Bursan wa l- 'urjan wa l- 'umian wa l-Hulan. Daru l-Jeel, Beirut.

Al-Makhzoumi, Mahdi. 1986. Fi n-Nahwi 1-Arabi: Naqdun wa Tawjih. Daru r-Ra'idi 1-Arabi. Beirut.

As-Samirra' I, Fadhil. 2000. Ma'ani n-Nahw. First Edition. Daru 1-Fikr. Amman.

As-Samirrai, Ibraheem. 1966. Al-fi'lu wa Zamanuhu wa Abniyatuhu. Matba'at al-Ani. Bagdad.

Ayad Seleem Mansour. 2012. Difficulties in translation of the English Present Perfect Simple and the Past

Perfect Simple into Arabic and some suggested solutions. Al-Ustath 200, Baghdad University, Iraq.

Az-Zajjaji, Abu 1-Qasim. 1986. Al-Iydhah fi n-Najw. Fifth Edition. Mazin al-Mubarak (verifier). Daru nNafais, Beirut.

Az-Zamakhshari, Abu 1-Qasim. 1993. Al-Mufassal fi Sin'ati l-Irab. First Edition. Ali abu Milhim (verifier). Makjabatu 1-Hilal. Beirut.

Az-Zubaidy, Muhammad Ibn Muhammad. 2001. Taju l-Arous. Daru 1-Hidayah.

Baker, Mona. 1992. In Other Words: A Coursebook on Translation. New York: Chapman and Hall, Inc.

Benmamoun, Elabbas. 2000. The Feature Structure of Functional Categories: A Comparative Study of Arabic Dialects. Oxford: Oxford University Press. 
Brustad, Kristen. 2000. The Syntax of Spoken Arabic: A Comparative Study of Moroccan, Egyptian, Syrian, And Kuwaiti Dialects. Georgetown University Press.

Catford, J. C Ian. 1965. A Linguistic Theory of Translation. London: Oxford University Press.

Celce-Murcia, Marianne, and Dina Larsen-Freeman. 1999. The Grammar Book: an ESL/EFL Teacher's Course. Newbury: Heinle and Heinle publishers.

Eisele, John C. 1992. Egyptian Arabic Auxiliaries and the Category of Aux. In Perspectives on Arabic Linguistics: Papers from the... Annual Symposium on Arabic Linguistics 4: 143.

Abdelkader Fassi, Fehri. 1993. Issues in the Structure of Arabic Clauses and Words. Dordrecht: Kluwer.

Ghazala, Hassan. 1995. Translation as Problems and Solutions: A Course book for University Students and Trainee Translators. Malta: ELGA Publication.

Gadalla, Hassan A. H. 2006. Translating English Perfect Tenses into Arabic: A Comparative Study of Two Translations of Pearl Buck's novel 'The Good Earth' In Babel, International Journal of Translation. John Benjamins 52 (3): 243-61.

Gadalla, Hassan A. H. 2017. Translating Tenses in Arabic-English and English-Arabic Contexts, UK: Cambridge Scholars Publishing.

Ibn Al-Atheer, Majdu Din. 1979. Ghareebu l-Hadeeth wa l-Athar. Taher Al-Zawi (verifier), AlMaktabatu 1-Ilmiyyah, Beirut.

Ibnu 1-Marzuban. 1991. Al-Kitabatu wa t-Ta'beer. $1^{\text {st }}$ Edition. Hamid Qutaybi (verfier). Daru 1-Basheer.

Ibnu 1-Warraq, Muhammad ibnu Abdi 1-Laahi. 1999. Illalu n-Nahwi. 1 ${ }^{\text {st }}$ Edition. Mahmud d-Darweesh (verfier). Maktabtu r-Rushdi s-Sa'udiyyah.

Ibn Jinni, Abu 1-Fath Uthman. 2005. Al-Luma' fi al-Lughatil Arabiyyah. Fa'z Faris (Virifier). Daru 1Kutubi th-Thafqafiyyah. Kuwait.

Ibn Ya'eesh. 2001. Sharhu l-Mufassal. Introduction by Emil Ya'qoub. Daru 1-Kutubi 1-Ilmiyyah. Beirut, Lebanon.

Ibnu s-Sarraj, Muhammad. 1988. Al-Usoul fi n-Nahw. Abdu 1-Husein 1-Fatli. Mu'assatu r-Risalah. Beirut.

Jelinek, Mary Eloise. 1981. On defining categories: aux and predicate in colloquial Egyptian Arabic. The University of Arizona.

Ingham, Bruce. 1994. "Modality in the Arabic Dialect of Najd. In Caubet D. and Vanhjove, M (eds.), Actes des Premeires Journees Internationales de Dialectolgie Arabe de Paris. Publications Langues ' $O: 185-200$

Jespersen, Otto. 1968. The philosophy of Grammar. London: George Allen and Univin Brothers LTD.

Jelinek, Eloise. 1983. Person-Subject Marking in Aux in Egyptian Arabic. Linguistic Categories: Auxiliaries and Related Puzzles. Categories 1, 21.

Joseph E. Aoun, Elabbas Benmamoun, and Lina Choueiri. 2010. The Syntax of Arabic, Cambridge University Press.

Juhfah, Abdu 1-Majeed. 2006. Dirasatu n-Nasaqu z-Zamani lil-Af'al. First Edition. Dar Tubqal li n-Nashr, Casablanca, Morocco.

Karin C. Ryding. 2005. A Reference Grammar of Modern Standard Arabic, Cambridge, New York, Melbourne, Madrid, Cape Town, Singapore, São Paulo.

Md. Akan. 2019. An Analysis of Arabic-English translation: Problems and Prospects. ALLS 10 (1): 58-65. 
Awareness of BA Translation Students of the Arabic Grammatical Aspects and their Translations into English: A Comparative Study

Newmark, Peter. 1988. A Textbook of Translation. New York, Prentice Hall International.

Obeidat, Mohammed. 2014. A Linguistic Approach to Translating the English Past Perfect Aspect into Arabic. English Language and Literature Studies 4 (1).

Patrick, R. Bennett, and Winona Lake. 1998. Comparative Semitic Linguistics A Manual, Indiana, Eisenbrauns.

Salkie, Raphael. 1989. Perfect or Pluperfect. What is the Relationship?" Journal of Linguistics 25.

Sekhri Ouided. 2008. Problems in Translating Tenses from English into Arabic the Present Perfect: A Case Study Dissertation. MA thesis. Mentouri University.

Sibawaihi, Amr ibnu Uthman. 1988. Al-Kitab. Abdu s-Salam Haroun al-Khanji (verifier). Third Edition. Cairo.

Wright, William. 1898. A Grammar of the Arabic Language. Translated from the German of Caspar and Edited with Numerous Additions and Corrections, Third edition. Vol ii. Cambridge university press.

Yasir Alotaibi. 2014. Conditional sentences in Modern Standard Arabic and the Taif Dialect. University of Essex.

Yasir Alotaibi. 2017. Analysis of auxiliaries in Modern Standard Arabic. Journal of Faculty of Languages \& Translation 12 II.

Younes Zhiri. 2014. The Translation of tense and aspect from English into Arabic by Moroccan undergraduates: Difficulties and solutions. AWEJ 5 (4).

Wills, Wolfram. 1982. The Science of translation: Problems and methods. Tubugen: Gunter Narr Verlage. 


\section{Appendix}

\section{The Test}

Choose the alternative that is the closest equivalent to the given Arabic text.

1. كان الطالب قد ذهب إلى المدرسة عندما وصلنا

a. The student had gone to school when we arrived. (Answer)

b. The student was going to school when we arrived.

c. The student went to school when we arrived.

d. The student will have gone to school when we arrive.

2. كان الطالب يدرس عندما وصلنا.

a. The student was studying when we arrived. (Answer)

b. The student had studied when we arrived.

c. The student has studied when we arrived.

d. The student has been studying when we arrived.

3. كان الطالب ما يزال يدرس عندما وصلنا.

a. The student had been studying when we arrived. (Answer)

b. The student is studying when we arrive.

c. The student has been studying when we arrived.

d. The student will have studied when we arrive

4. لقد أكل الولد تفاحة.

a. The boy has eaten an apple. (Answer)

b. The boy has been eating an apple.

c. The student had been eating an apple.

d. The student will have eaten an apple.

5ل يجري اللاعب في الملعب الآن؟

a. Is the player running in the playground? (Answer)

b. Had the player been running in the playground?

c. Will the player be running in the playground?

d. Has the player run in the playground?

6. ما يزال أحمد يدرس منذ هذا الصباح.

a. Ahmad has been studying since this morning. (Answer)

b. Ahmad was studying this morning.

c. Ahmad studied this morning. 
Awareness of BA Translation Students of the Arabic Grammatical Aspects and their Translations into English: A Comparative Study

d. Ahmad is studying now.

7. سيكون الرجل قد وصل إلى بيته قبل يوم غد.

a. The man will have reached his home by tomorrow. (Answer)

b. The man has reached his home by tomorrow.

c. The man had reached his home by tomorrow.

d. The man reached his home by tomorrow.

8.

a. Ali will have studied for two years when he graduates. (Answer)

b. Ali will have been studying for two years when he graduates.

c. Ali will study for two years when he graduates.

d. Ali is studying for two years when he graduates.

9تكون الفتاة تدرس عندما يصل المعلم

a. The girl will be studying when the teacher arrives. (Answer)

b. The girl will have studied when the teacher arrives.

c. The girl will study when the teacher arrives.

d. The girl will be studied when the teacher arrives.

10. سيكون علي ما يزال يدرس عندما نصل

a. Ali will have been studying when we arrive. (Answer)

b. Ali will have studied when arrive.

c. Ali will study when he graduates.

Ali is studying when we arrive. 